\title{
Importance of Communication in Law
}

\author{
Anwesha Pathak, Shivangi Sinha, Astha Srivastava
}

\begin{abstract}
The two horrible conditions ahead of time than the organizers worldwide are to diminish the stack at the conventional fills and to reduce the continually developing basic spoiling. This test is proposed to discover probably the execution of the DI diesel motor at various loads when fuelled with mixes of palm methyl esters and diesel. The primers have been pushed on a completely utilized diesel motor without changes. Every one of the appraisals were consistent usa of america and outfitted toward dependable pace. The impact of moving weight develop to be assessed the volume that brake warm temperature ability, mass flow rate, brake one of a kind gas use and fumes gas temperature. Exploratory impacts show that at complete weight conditions, the B-20, B-40and B-60 mixes bring 33.23\%, $32.81 \%$, $32.39 \%$ and 31.ninety seven\% higher brake heat usefulness than sole diesel freely. It wound up confirmed that the brake warmth ability of palm biodiesel is higher than that of diesel, and it is a delayed consequence of the oxygenated atom of biodiesel which acknowledges total ingesting of the biodiesel fuel. In addition the mass development rate of biodiesel is evidently superior to anything that of diesel fuel; it is through method for exact capacity of the calorific estimation of biodiesel is a ton parcels less appeared in one another way as far as diesel gas. At the reason for results obtained from this test utilizing palm biodiesel as a fuel is proposed for the utilized as a piece of a diesel motor with diesel mixes.
\end{abstract}

Catchphrases: biodiesel, esterification, pyrolysis, emulsification, blends.

\section{INTRODUCTION}

Communication is an essential part of every individual. A good communication can lead to better understanding and ultimately result in the growth of the individual or the economy. Information Communication Technology refers to various technological tools which give access to useful information via means of telecommunications. It includes all the products that help in restoring, retrieving and transmitting the information digitally. ICT also helps in directing these technologies to bring to use each other for one another. The tools include internet, intranet, email, wireless technology, cell phones and many more.

The increase in the use of ICT in daily life is like a boon to the growing trends of world. It is because of the rapid use of ICT the world has become a Global Village. The work which used to take months and hours to be completed, now because of ICT have become very easy and less time consuming. Legal practice is concerned with law and has various dimensions attached to it. ICT helps the legal practice as the legal practice involves a lot of documentation, storing of information and its retrieval.

The sources of ICT are as follows:
1. Computer
2. Email

$\begin{array}{ll}\text { 3. } & \text { Internet } \\ \text { 4. } & \text { Intranet } \\ \text { 5. } & \text { Extranet } \\ \text { 6. } & \text { Social Media } \\ \text { 7. } & \text { Cell Phones } \\ \text { 8. } & \text { Software }\end{array}$

\section{METHODOLOGY}

The researcher in this article has carried out a complete doctrinal research. There are various skills which a lawyer is supposed to follow. The foremost skill is Communication. Communication is the most essential tool for any individual to flourish in their respective fields. Communication process involves three steps:

1. Sender- Whenever we want to communicate any information, there is always a sender. He is the one to start the communication. He is the source of the information.

2. Message- Communication involves message. Message is the most crucial part of the communication process

3. Receiver- He is the last chain in the whole process. $\mathrm{He}$ receives the message send by thesender. Once the message is received, he/she tries to interpret the message, understand it and then act accordingly.

\section{FINDINGS}

\section{A. IMPORTANCE OF COMMUNICATION}

1. Communication acts as a tool for coordination. The senior shall inform its subordinates about their various functions and roles that they have to carry out. It helps to enhance interpersonal skills of the employees.

2. Communication helps in efficient and fluent working of the entire system. This will help the working environment grow and develop

3. Poor communication may lead to faulty decision making which may eventually result in poor development of the economy. Communication is a very important tool for development I any field.

4. Two way communications helps to increase mutual understanding between the senior and junior.

5. Good Communication skill helps to boost morale of every individual. 
B. TYPES OF COMMUNICATIONS

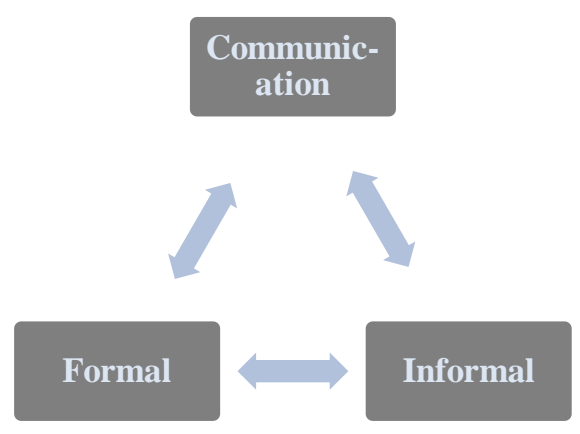

1. Formal Communication is the one which circulates through a proper medium. The senior shall pass on the information to their junior and then further. This kind of information can be

oral or in writing. Formal Communication can be further dived into:

a. Vertical Communication- This type of conversation flows upwards towards downward direction. This means that the juniors shall pass on the required information to the seniors. It can be any kind of information.

b. Horizontal Communication- This type of information basically deals with communication being carried out within the different departments of the office. Each unit circulating information amongst each other in a systematic way

2. Informal Communication is one which does not follow any systematic way. Any person in the organization shall communicate with anyone else without following any procedure. Such information even spreads widely and often gets imprecise. The source of such information is difficult to discover. This is usually called the grapevine network.

\section{BARRIERS TO COMMUNICATION}

1. The foremost barrier that we face as lawyers is language barriers. India being a diverse a country it and has many languages. We cannot know all the languages and thus it becomes a problem for us to communicate with people who do not know the common languages.

2. There are often instance which create a problem due to lack of proper internet connection. The receiver is unable to receive the messages only that are sent by the sender.

3. Distance between the sender and the receiver also is very important for carrying out better communication. Short distances have better communication than long distance.

4. Sometimes ego and attitudes of people also create hindrance for carrying out communication effectively. This then results in poor management and inefficient work.

\section{VERBAL COMMUNICATION}

1. We should be friendly in the manner in which we talk and present ourselves. The person that we are talking to should also feel that he can speak to us without any kind of pressure.

2. One must always think before they speak. They should not just say anything anywhere. We must talk wisely.
3. One must only talk little. They should go on without making sense. We must talk only that much how much we are supposed to. We should limit ourselves.

4. While talking we must always be humble. We shall not portray any kind of attitude or rude behavior while talking to someone.

5. We must be very confident while speaking. We shall speak in such a way that we are able to convince the person.

6. One must never forget that $\mathrm{I}$ is equally important to listen to the person who is speaking to us carefully. Only then can we respond in the most effective way.

\section{E. NON VERBAL COMMUNICATION}

When we talk about communication we often refer to words and medium of speech. But there is an effective role of non verbal communication which plays a very important role in building up interpersonal skills.

Non verbal communication includes facial expressions, pitch of voice and gestures displayed through body.

\section{F. $\quad$ Importance of Non Verbal Communication}

1. Non verbal communication helps to understand words better. There are certain actions that we do which give a better understanding and help the other person to grasp in a better way.

2. Facial expressions help to convey information about their emotional state.

3. Sometimes if we tend to spend a lot of time with each other, we tend to behave or adapt each other's mannerism. This is an effect of non verbal communication.

4. There are certain signals that we tend to show that we have finished speaking, these also are very important manners to continue communication.

5. Personal Space also known as Proxemics is a very important criteria for non verbal communication. People need $t$ understand when they should give others time and even when they should take out time for themselves.

6. Eyes also play an important role in carrying out verbal communication.

7. Communication through touch also known as Haptics comes under non verbal communication. People tend to touch while speaking, and we have to know or understand what kind of a touch it is. Like when a mother touches her child with care.

\section{RESULTS AND DISCUSSIONS}

Non verbal communication does not involve words thus it becomes very difficult to interpret the gestures, facial expressions and other non verbal techniques.

Sometimes non verbal communications are also done unconsciously. It is difficult to control facial expressions sometimes and sometimes we unknowingly give away such signals which we do not want to. 


\section{CONCLUSION}

The legal profession is one of the classic professions in which confidentiality plays a central role. As lawyers, we have to deal with a number of issues, like duty of discretion, the right to refuse to answer questions, professional confidentiality and a specific code of conduct. Clients must be able to speak freely with their lawyer at all time. This means that in the legal profession, communication is central. Between lawyers, with clients, with other parties, the court, etcetera. There is always a lot of time pressure, because hourly rates are costly and timing is often important. When time is of the essence, the limited user friendliness of email clients will not do. More and more legal professionals turn to services like WhatsApp for quick communication. Exchanging information this way is swift and simple, but not secure. Having confidential information be shared regardless of industry standards and international regulations (the GDPR) is unacceptable.

We have got the solution; the Alter desk platform is secure and has been developed in the Netherlands. Plenty of companies are now using Alter desk to exchange confidential information.

\section{REFERENCES}

1. Srivastava, Astha. "Patent And Competition Interface: Issues And Challenges In India." Int. j. of Social Science and Economic Research, vol. 4, no. 2, Feb. 2019, pp. 1521-1527, ijsser.org/more2019.php?id=111.

1. Sarda, M., Deshpande, B., Shringarpure, S.: "Smart city - Use of technology and the needed labor reforms", International Journal of Innovative Technology and Exploring Engineering 2018.

2. Sarda, M. Deshpande, B., Deo, S., Karanjkar, R.: "A comparative study on Maslow's theory and Indian Ashrama system", International Journal of Innovative Technology and Exploring Engineering, 2018.

3. Sarda, M. Deshpande, B., Dharm, J., Dhere, V.: "Different aspects of environmental laws", International Journal of Recent Technology and Engineering, 2019.

4. Deshpande, B. Girme, A. : "Research methods made simple", International Journal of Innovative Technology and Exploring Engineering, 2019.

5. Girme, A. Deshpande, B.: "The life line of human beings-"Right to potable water", International Journal of Recent Technology and Engineering, 2019.

6. Sinha, S. Deshpande, B., Deo, S., Vedpathak, S. "Potential appeal mechanism by consent: Arbitration", International Journal of Recent Technology and Engineering, 2019.

7. Srivastava, A., Sinha, S.:"Cyber Delinquency: Issues and Challenges under Indian Legal System", International Journal of Engineering and Advanced Technology (IJEAT) 2019

8. Anuradha G., Revolutionary Yogic Agriculture, International Journal of Recent Technology and Engineering (IJRTE) ISSN: 2277-3878, Volume-8 Issue3, September 2019

9. Deo, S., Deo, S.: "Cybersquatting: Threat to domain name", International Journal of Innovative Technology and Exploring Engineering, 2019.

10. Deo, S. Deo, S.: "Domain name and its protection in India", International Journal of Recent Technology and Engineering, 2019.

11. Dubey, R., Sakhalkar, U.: "A critical analysis of rising intolerance and growing polarisation: Lynching", Journal of International Pharmaceutical Research, 2019.
12. Ujjwala Sakhalkar, Community Participation for access to Justice to children: A road map for future, International Journal of Recent Technology and Engineering,2019.

13. Salil Shringarpure, Internet Trolling: Analyzing the legal myths and facts, International Journal of Engineering and Advanced Technology, 2019.

14. Shaikh, A., Khandare, J.: "International parental child abduction in United States of America and India", International Journal of Engineering and Advanced Technology, 2019.

15. Khandare, J., Shaikh, A.: "When life becomes death: A stifling story of air pollution", Journal of International Pharmaceutical Research, 2019

16. Pathak, A. Mishra, A.: "Human trafficking in India", Journal of International Pharmaceutical Research, 2019

17. Bendale, U., Dhere, V.: "Right of aged persons to live with dignity: A socio-legal perspective", International Journal of Innovative Technology and Exploring Engineering, 2019

18. Dhere, V., Bendale, U.: "Impact of smart city on social relations", International Journal of Innovative Technology and Exploring Engineering, 2019.

19. SukrutDeo and Dr. SapnaDeo, "Cybersquatting: Threat to Domain Name", International Journal of Innovative Technology and Exploring Engineering, 2019

20. Srivastava, A. Sinha, S.: "Anti dumping policy and its effect on indian pharmaceutical sector ",International Journal of Engineering and Advanced Technology, 2019. 